\title{
MONTE VERITÀ AND GLASTONBURY: NEW ROMANTIC "CRIES" FOR “MOTHER GAIA". ANALYSIS OF “NEW" SPIRITUALIT(IES) WITHIN THE 20TH-CENTURY AND THE CONTEMPORARY WEST
}

\author{
SILVIA CARNELLI
}

\begin{abstract}
:
The communities of Monte Verità and Glastonbury are two representatives of the "alternative wave", or rather of the "counterculture" that has been spreading throughout the West since the beginning of the 20th century. Rooted in 19th- century Romanticism, it nowadays survives within the so called "New Age".

This "new" cultural phenomenon, which has been emerging partly in the spiritual and partly in the political field, is characterized by an eclectic mixture of ways of expressions: naturism and homeopathy, that are often put in relation to ecologist discourses; mysticism, theosophy, paranormal research and spiritual healing; forms of revival of pre-Christian religions (e.g. New Paganism), getting intertwined with Eastern imports (e.g. yoga and Asian medicine traditions); movements of space-place-sacralization such as Ley-Lines Hunting and Feng-Shui.

Despite the differences in their origin and in their implementation, all these proposed "new" ways of life share the same countercultural goal: to restore the deficits of the modern industrialized, capitalized and medialized society - amongst others by regenerating the substantial link between the human being and the forces of nature (particularly of "Gaia"; the earth). As a result of the popularity of these movements, the Western society has been experiencing a translation in the relationship between the "human" and the "beyond" in the last two centuries, as well as in the conception of religion itself and of its collective role. Starting from two significant examples of "alternative" communities in Europe, this paper develops a reflection about the relocation of traditional religious beliefs in the post-secularized West.
\end{abstract}

\section{Keywords:}

20th-century Counterculture; 21st-century New Age; "Back to Nature" Narratives; Feminine Spirituality; Holism; Homeopathy; Ecology

JEL Classification: Z00

\section{Authors:}

SILVIA CARNELLI, Catholic University Eichstätt-Ingolstadt, Germany, Email: silvia.carnelli21@gmail.com

\section{Citation:}

SILVIA CARNELLI (2016). Monte Verità and Glastonbury: New Romantic "Cries" for "Mother Gaia". 
Analysis of "New" Spiritualit(ies) within the 20th-century and the contemporary West. International Journal of Social Sciences, Vol. V(2), pp. 1-18., 10.20472/SS.2016.5.2.001 


\section{Introduction}

Generally speaking, religion has always been a moving concept within human history. Indeed, depending on the socio-political context, the basic paradigms and theorizing concepts of a certain community have repeatedly undergone some radical changes, bringing about a transformation even to the long-established and apparently unchangeable traditions. In particular, according to the Metzler Lexikon, two fundamental aspects are to be ascribed to religion: first, normativity, or rather the establishment of values, rules and behavioural guidelines; second, aesthetics, or rather the translation of the normative contents into narratives and rituals (Hammer, 2013, 644). Actually, both aspects are thought to provide a fixed structure in order to guarantee the transmission of the culture itself, as well as its stability on the long term. However, history shows how both of them continually experience dramatic changes. Revolution, transformation, and relocation of cultural patterns: these are the three basic steps of every history, particularly in the realm of the spiritual. Therefore, the analysis of the multiple and sometimes even contrasting developments taking place within the religious traditions of an identified human community constitutes one of the main tasks of cultural history.

Within the Western context, this three-step process seems to have started anew since the beginning of the $20^{\text {th }}$ century - a period which is commonly referred to within humanities as the "turn of the century" (German "Jahrhundertwende"). In this regard, Hart (1890) claimed that this turn was not just a change in date numbers, but rather it signed a crisis within the Western conception of reality itself (Pytlik, 2005, 12). Inevitably, such structural changes have an impact also on the way/s of relating to the "spiritual". As a matter of fact, in the same period the long-established Christian Western religious tradition (re)started to face a new wave of challenging movements, amongst others the German counterculture. Furthermore, this challenge to the constituting levels (normativity and aesthetics) of traditional Christianity continued to develop throughout the century, resulting in its last decades into the so called "New Age". This umbrella term reunites the great variety of spiritual currents and religious phenomena characterized by a highly degree of syncretism and by a holistic attitude that are still continuing to spread within contemporary Western society (Heelas, 1996, 2). In general, this kind of currents believes in an approaching "new age" in the zodiacal constellation that will be followed by the diffusion of new holistic spiritual practices, different from those of the patriarchal Christian Church of the "old age" (Prince and Riches, 2000, 55).

As for each historical "turn", it is necessary to take into account the economic and the social context of the period. In the case of the "Jahrhundertwende", the dominant socio-economic model was based on money exchange, industrial mass production, territorial expansion, rapid scientific and technological improvement (Berhorst and Berg, 2014, 57). Actually, this model has received different reactions from the very beginning. On the one hand, it has 
been glorified by the Positivist euphoria that is still to be found within the contemporary globalized capitalistic society; on the other hand, it has been strongly criticized. The countercultural movements that have been mentioned in the previous paragraph belong to the second group. Interestingly enough, their critical attitude brought together the economic and the spiritual aspect by linking economic improvement to secularization.

However, this "crisis of faith" and "loss of values" as it has been denounced by the counterculture is worth a deeper analysis. In fact, as the second paragraph has suggested, the increasing detachment from the traditional forms of faith can be analysed in terms of a "crisis of belief" in the conception of the human being/earth relationship. In other words, the recent decline of influence of the official Christian churches in the West cannot be considered as a mere consequence of material prosperity, but rather as a chapter within the constitutive historical process of revolution, transformation and relocation of cultural patterns. In this context, this paper aims to analyse the $20^{\text {th }}$-century counterculture and the contemporary New Age phenomenon as revolutionary, transformed and relocating expressions of the Western conception of being "alive", or rather of "being in the world", as Merleau-Ponty $(1966,12)$ defines it.

This paper is structured in two main parts. The first part (chapters 1 and 2) describes the history of Monte Verità, a central place for the German-speaking counterculture of the "Jahrhundertwende", and of Glastonbury, the capital of the more recent Hippie and New Age culture. The second part (chapters 3 and 4) focuses on the analysis of the metaphysical discourses supported by the members and the protagonists of both communities, showing their common roots in the Romantic heritage as well as their tendency to feminine spirituality. Finally, the last chapter of the second part points to some major features of their approach to religion: syncretism and holism. Basically, this study makes use of an interpretative methodology which starts from the personal experience of the members of the communities (collected through the historical sources as well as through interviews) in order to reflect on their meaning-making practices and on the resulting values.

However, a scientific enquiry of the "alternative" phenomena presents some difficulties, one of them being related to the terminological nebulosity. In fact, the main terms around which the research revolves around - "alternative", "religious" and "spiritual" - are themselves highly critical. This is mainly due to their "open-endedness", or rather to their potential of assuming a different connotation according to the context. Nevertheless, in order to avoid a theoretical discussion that would take too far from the focus of the paper, the author of the study suggests three possible and rather practice-oriented definitions:

a) "Religious" is a conception or an attitude included within the long-established and officially recognized system of a specific community; an example for it is the ritual of Christian baptism for babies. This is performed on large scale within Western 
society, even by those who neither take part regularly to the other rituals proposed by the Church, nor practice its principles in everyday life.

b) "Spiritual" is a conception or an attitude which is related to the "other" realms of the "super-human" and of the "super-natural". These can be either supported by religious structures or they are enfolded by minorities (not included or regulated within public law) or at private level. For this reason, the "alternative" currents presented in the paper will be mainly referred to as "spiritual", although some of them (e.g. the New Pagans) have acquired the status of religion by now.

c) In this context, "alternative" is a conception or an attitude which challenges the spiritual as well as the ritual forms of the traditional and legal religious system.

\section{Monte Verità (Switzerland).}

Monte Verità (literally "Mountain of Truth") is a hill over Ascona, a little lake village in the the Swiss canton Ticino. In the year 1900, a group of five German-speaking exponents of the "counterculture" founded a community to practice a new way of life: an "alternative" with regard to the modern middle-class city-life which, because of its alienation from nature and the pollution due to the industry, was considered to make people ill (Noschis, 2011, 16). For instance, the members of the community followed a strict vegan and/or vegetarian diet with no coffee, alcohol and tobacco; they refused inoculations, wore exclusively linen and cotton clothes and nourished themselves only with the products of their garden. Not only was this way of life considered to be a valid alternative to modern city life, but it was soon also proposed as a healing practice. For this reason, the community was almost immediately transformed into a sanatorium open to the public in which visitors could experience this life close to nature for a while. They lived in so called "air-cottages" (woodhuts), practised "sun- and air-baths" and open-air gymnastics (Voswinckel, 2009, 16, 22 ff.) and other bodily activities including sports like Nordic waking and tennis, Rudolph von Laban's avant-gardist body-spirit dance and yoga (Wedemeyer, 2001, 100 ff.).

Apart being a sanatorium/healing center, particularly during the first half of the century the community of Monte Verità became a meeting point for other people who, being in rupture with the social norms of the time, searched for "alternative" ways of experiencing the human/world relationship (Noschis, 2011, 138). In this context spirituality, considered to be one of the highest ways to come in contact with the "other-human" in and through the world, constituted one of the main fields of experimentation, both for the members of the community themselves as well as for its occasional visitors. First, Monte Verità was chosen for a project of a theosophist cloister called "Fraternitas", guided by Alfredo Pioda and Franz Hartmann, which was not realized. Second, after its transformation into a sanatorium, the freemasons lodge "Confrérie des Illuminés Hermétiques" and the occultist order "Ordo Templis Orientis" organized several conferences there (Schönenberger, 1978, $66,75 \mathrm{ff}$.). 
What's more, even after the departure of the original founders after World War I the search for other ways to experience and practice spirituality continued in other forms. The following acquirer of the place Baron Eduard von der Heydt transformed the buildings of the original community into a place for contemporary, Eastern and primitive art (Folini, 2000, 32). Similarly, in 1932 the theosophist Olga Fröbe-Kapteyn continued the research into the fields of non-Christian and non-Western religions by founding the so called "Eranos Conferences" in a private residence on the lake's shore, with the support of Carl Gustav Jung. During these yearly symposia, which still continue nowadays, well-known scholars (amongst other Mircea Eliade) studied several Eastern spiritual and religious traditions, first of all yoga and Taoism, discussing about their possible integration within the already existing traditions of the West (Dedola, 2011, 48). In addition to this kind of spiritual (re)search, the Eranos leaders also dealt with the question of the "genius loci", or rather on the intrinsic energy emanated by "natural" places (Bremer, 2004, 79).

Nowadays, although the radical "alternatives" have been rather confined to the archives, Monte Verità continues to offer several impulses in the direction. First, on the basis on the discoveries made in the 1940s by the painter and hobby archaeologist Ernst Frick around the Celtic settlement on the nearby hill called "Balladrum", the hunting for "Ley lines" (earthenergies and places of magnetic power influencing the human being) has been brought forth, so that the Monte Verità association offers a tour called "Excursion to Places of Power". For instance, this tour starts on the terrace in front of the main building. This latter is covered by a colorful mandala/stoned-path called "Chiara's Rainbow" which has been recently constructed to let visitors experience the special energy of the place. Furthermore, in the same area of the original settlement, next to the main building, the Monte Verità Tea House, constructed in the so called "Zen Garden", offers workshops and a detailed introduction to the Japanese tea culture (Monte Verità, 2016). Finally, the enquiry of "alternative" sources for healing through the integration of the spiritual has also been discussed within the meetings of the American medical association „Balint Society“, whose focus lies on the therapeutic potential of emotion and personal understanding in the doctorpatient-relationship. Since 1968 several of its conferences about the holistic approach in medicine have taken place in the Monte Verità hotel (Martinoni, 1995, 5).

\section{Glastonbury (England).}

Glastonbury is a town located in Somerset, in South-West England. Differently from the Swiss community, the place has always been a major Christian pilgrimage center because of the great Glastonbury Abbey, whose cemetery keeps the relics and the tombs of several British saints and kings, amongst others of the legendary King Arthur (Westwood and Simpson, 2005, 642). In the context of the Arthurian legend, another important spot in the area is the hill called "Glastonbury Tor", on which the Celtic and the Christian religion get intertwined. In fact, according to the various local legends the Tor is supposed to be both 
the entrance of the Celtic "Underworld" (Simek, 2012, 142) and the place where the first Christian community guided by Joseph of Arimathea settled down (Capt, 2008, 10).

At the beginning of the $20^{\text {th }}$ century Glastonbury's reputation of being the legendary "Isle of Avalon" linked to the Celtic Arthur attracted an esoteric-inspired group of people led by Wellesley Tudor Pole and Dr. Goodchild. They initiated a spiritual community dedicated to the relic of the Holy Grail, a blue cup that had been found by one of the women of the group in a well of the Glastonbury area (Benham, 1993, 50). In the same period, the architect and freemason Frederick Bligh Bond, who was in contact with Dr. Goodchild's group, uncovered several of the Abbey's ruins by means of "automatic writing" - the unconscious channeling of words provided by a "super-human" force through an individual mind in trance. In that case, it was the spirit of a monk of the Abbey who was said to have spoken to Bligh Bond, directing his excavations (Hopkinson-Ball, 2007, 58). At the same time, Bligh Bond stood in dialogue with the so called "Chalice Well Training College for Women" founded by the "avant-gardist" educationalist, theosophist and writer Alice Buckton. Inspired by the ideas of education of Froebel and Pestalozzi, she promoted a "naturebased" school form focused on gardening and environment care, household management and craftwork, cooking/dietary studies and music/drama performances (Benham, 1993, 147).

However, all these "alternative" spiritual impulses boomed first in the second half of the $20^{\text {th }}$ century. Since the 1970 s, with the revival of the Glastonbury Festival in the nearby village of Pilton, Glastonbury has become a meeting point for Hippies, anarchists, anticapitalists and the Green. Indeed, along with entertainment this kind of manifestation has been often used to verbalize that call for respect for nature and for "a spiritual awakening" shared by all these groups (Aubrey and Shearlaw, 2005, $22 \mathrm{ff}$.). Furthermore, differently from Monte Verità, the so called "alternative" spirituality is nowadays experiencing its golden age in Glastonbury: the town itself is filled with esoteric libraries, tarots and crystal shops, vegetarian/vegan cafés, as well as yoga centers and alternative healing centers focused on herbalism and acupuncture, energy healing (with crystals, colors and sounds) and channeling (Prince \& Riches, 2000, $96 \mathrm{ff}$.). In particular, the biggest center for alternative medicine in the town is the Chalice Well. For instance, the Chalice Well Trust organizes international "Healing weekends" and seminars in non-European (mostly Eastern) medical practices, including e.g. Aromatherapy, Gong Baths, Shiatsu, Reiki and Spiritual Healing (Chalice Well, 2016).

Finally, since the 1970s Glastonbury has also become a spiritual and religious center for two New Pagan communities: the Glastonbury Order of Druids and the Goddess Movement. This latter has collected several feminine Celtic local divinities in its temple situated in the town center (Jones, 1990, 3). As for the Druids, the Goddess worshippers mostly hold their seasonal rituals on the Glastonbury Tor. In fact, particularly after the 
publication of John Michell's esoteric-geomantic writings in the 1970s, the Tor has become known as an energy spot lying on a powerful line (again, a "Ley line"), whose vibrations are considered to be important both by the New Pagans as well as by the so called "Ley Line hunters" and geomancy researchers (Michell, 1983, 182 ff.).

\section{New Romantic "Back to Nature" Narratives and "Cries" for Gaia.}

As it has already been mentioned in the introduction, the second part of this paper aims to analyze the metaphysical/metaphorical discourses of the "alternative spiritualities" of the $20^{\text {th }}$ and $21^{\text {st }}$ century on the basis of the movements gathering around Monte Verità and Glastonbury. Finally, this kind of analysis is used to illustrate the relocation of certain spiritual (and not only) paradigms that have been affecting Western society in the most recent times.

First of all, the variety of movements and groups gathering in both places share a common "mission": the rebellion against the life conditions of the modern industrial and "financialized" cities and the revival of a way of life which is mostly associated with the preindustrial past. Generally speaking, this "mission" derives from a specific approach which could be defined as "naturist". Actually, the term "naturism" has already been used within cultural history in reference to the nudist practices performed by several countercultural groups at the beginning of the $20^{\text {th }}$ century, amongst others by the original founders of Monte Verità (Landmann, 2000, $106 \mathrm{ff}$.). Instead of that, this paper suggests to enlarge the use of the term to describe the human/world relationship manifested by the various movements of the "alternative" culture of the last two decades. In fact, one of the major "alternative" ideas consists in transforming the contemporary Western society by "going back to Nature" (Hofmann, 1906, 6). The nudist dances and the open-air bodily activities of the first community on Monte Verità, focused on moving freely and naked in nature, were actually meant to let people drop out of the artificially determined and nature-alienated lifestyle of the cities in order to come closer to the original dimension of human life. Just the same, the contemporary New Pagan rituals performed on the Tor or at the Chalice Well as well as the homeopathy practices offered within the holistic medicine centers of the town pursue the same goal: to come in contact with the forces of nature, being identified as the main source of life (Prince and Riches, 2000, 29).

In this context, "going back to Nature" is equated with the idea of "going back to Life". Furthermore, this "way" becomes a remedy for the constitutional deficits of the modern West:

a. The congestion with "matter" (commonly referred to as materialism): the surplus of "things" (be it from food and other consumption goods to mental stimuli) that are produced and consumed in masses, with a low consciousness of their "being"; 
b. The loss of "magic" (commonly referred to as secularization): the inability, or maybe even the refusal, to experience and to recognize the "other-than-human" elements in matter.

In this sense, a nature-closed and nature-oriented way of life should bring the human being in contact with the source of every-thing, restoring that substantial connection blended by the industrial-artificial. Thus, this immersion in the source has two effects. First, it allows everyone to recognize his/her own place in the world, or rather its role within the balance of the "cosmos"; second, it favors spiritual enhancement through a "renewed" sensibility (or rather sensitivity) for the invisible and mostly mysterious forces that regulate life on earth.

Interestingly enough, these "Back to Nature - Back to Life" narratives share a further element in common: the "Back" idea. In the cases of the $20^{\text {th }}$-century "life reform" and of the contemporary $21^{\text {st }}$-century "New Age", "back" is conceived both in spatial and in temporal terms. First, "back" is spatial insofar as the "alternatives" strive for a lifestyle immersed in nature, e.g. based on physical work in farms and woods - a dimension from which the city dwellers are physically and spatially detached. Second, this "back" has also temporal connotation, since the promoted lifestyle is mostly associated with a period of time antecedent to the beginning of the industrial era. In particular, the naturist approach describes this pre-industrial lifestyle as a sort of "golden past", since humanity is thought to have been closer to the source of life. Starting from this point of view, the $20^{\text {th }}$-century and $21^{\text {st }-c e n t u r y ~ " B a c k ~ t o ~ N a t u r e ~-~ B a c k ~ t o ~ L i f e " ~ n a r r a t i v e s ~ a r e ~ c h a r a c t e r i z e d ~ b y ~ t h e ~}$ nostalgia for the "Eden", or rather for a (more or less) imagined primordial world in which the human being lived as "one", which means in harmony with the holy cosmos (Eliade, 1984, 19).

Actually, the use of such metaphors can be partly traced back to the history of ideas of the previous centuries. Heroism of the individual, spiritualization of the world, nostalgia for a golden past: these three elements constitute the core repertoire of the Romantic Movement of the $19^{\text {th }}$ century (Heelas, 1996, $41 \mathrm{ff}$.). Indeed, without reducing the great complexity and multiplicity of Romanticism, it is possible to claim that these three elements characterize each of its expressions, although in different combination and intensity. As a matter of fact, the "Back to Nature - Back to Life - Back to Eden" rhetoric characterizes the images used by the first Romantics such as e Jean Jacques Rousseau's "noble savage" or Henry David Thoreau's "noble" life in the woods. Both well-known "narratives" revolve around the Romantic hero whose wisdom of "life", derives from the solitary confrontation with the "other" super-human, mostly nature. Consequently, the Romantic attitude looks at natural places as the incarnation of the "genius of life", or rather of the birth-giving and cosmoscreative forces - an attitude that finally has to bring back "magic" to a world (Kozljanič, 2004 , vol. 2, $159 \mathrm{ff}$.) which is full of things and empty of every-thing. 
For this reason, Heelas $(1996,42)$ considers $19^{\text {th }}$-century Romanticism as the basis for the "alternative" culture of the $20^{\text {th }}$ century as well as for the contemporary New Age phenomenon. In particular, Heelas (2008, $26 \mathrm{ff}$.) identifies the main focus of Romanticism with the search for that "spirit of life" that has to be found in each dimension of reality. Actually, this ambition has continued within the various "alternative" spiritual manifestations that have come out after the Romantic movement, from $19^{\text {th }}$-century "spiritualism", occultism and theosophy, to the life-reform and the later New Age. Interestingly enough, Heelas $(2008,46 \mathrm{ff}$.) points out that this same search for the "original whole One" was also translated into politics: from the narratives of the European totalitarian regimes (Nazis and Fascists) praising the "Volk" and its magical and ancient connection to the land, to the opposite party of the pacifist "Flower-Power" of the 60s emphasizing the importance of the absolute connection between the self and the earth. In the same way, McKay $(2000,174)$ agrees that, despite its rather secular and political connotation, the "green revolution" has drawn the public attention on the cure of the planet, or rather on the shared life-giving earth - a concern that still survives within the contemporary discussions about ecology and sustainability. In other words, the "spiritual alternatives" that have been analyzed so far can be seen as the "mystic" expression of a more general "cry" for transformation that has been shaking the West from the beginning of the modern revolution: to reconnect with the earth, with the elements, and finally with the spiritual dimension of every-thing through and in the "spirit" of the Green Gaia (Aubrey and Shearlaw, 2005, 142).

\section{4. "New" and "Alternative" Spiritualit(ies) of the Mother.}

This Romantic and New Romantic "archaic-mythical relationship" to nature (Kozljanič, 2004, vol. 1, 123), which is apt to emphasize its spiritual substance, shows another feature: the tendency to refer to the goal of the spiritual enhancement in terms of the feminine. In the case of the Western "alternatives" of the last two centuries, this tendency results in the description of the divine as "Mother Gaia". Really, it is not difficult to see the link between the "Back to Nature" narratives and a Mother-based spirituality: as the mother of (the) "All", nature constitutes the first dimension of the material in which the divine, identified with the life-giving aspect, gets materialized. For this reason, the feminine conception of the "otherthan-human" matches with (and partly implies) the New Romantic naturist approach that has been described in the previous chapter. Indeed, the desire for a "natural" way of life (alone in the woods, or rather in the garden of a self-supply community) presupposes the conception of "Nature" with capital letter: a physically-regulated combination of matter and motion (along with the mainstream of the modern scientific revolution) which is at the same time the manifestation of that mostly irrational and mysterious life-force. In other words, the naturist approach of the New Romantic "alternatives" is based on a pantheistic and hierophanical conception of nature, which identifies the "beyond" in its "within" (Eliade, $1984,15)$. Because of its essential "lively" and "life-creating" character, the spiritual force incarnated in this "Nature" is mostly identified as feminine. 
In this context, Monte Verità has been one of the first places, at least within the Germanspeaking context, dedicated to the intensive (re)search for the feminine in relation to nature. First of all, the original community led by Hofmann and Oedenkoven explicitly made use of the rhetoric of "coming back to Mother Earth" in the description of their countercultural project - first of all through a way of life that should reduce the human intervention as much as possible (self-sustaining agriculture) in order to become "one" with its eternal circles (Noschis, 2011, 17). Particularly one of the founders, the nature-apostle Gusto Gräser contributed to spread this metaphor of "Mother Earth" and the "Eternal Feminine" in his poems, in which nature is described as the "Mother", primary source of life, comparable to the Chinese Tao (Müller, 2016, poem 51). Finally, the "Great Mother" constituted also the main topic of the Eranos symposium in 1938, focused on the psychological aspects of the Mother-representations in different cultures and historical periods (Bernardini, 2011, 195 ff.).

Currently, Glastonbury represents one of the main European centers for feminine spirituality. This is mainly due to the presence of two New Pagan communities. Actually, these movements aim to revive and reconstruct the ancient natural religions, which in the case of Glastonbury correspond the local Celtic tradition. Consequently, the Druids focus on the celebration of astrological events like solstices and eclipses which are considered to be the highest expression of natural and cosmic forces (Hunt, 2003, $147 \mathrm{ff}$.). Furthermore, the feminine connotation of such life-giving natural forces lies at the core of spirituality and religion of the Goddess Movement led by Kathy Jones. To this purpose, its "pantheon" is composed by the natural goddesses (divine spirits of nature) of the preChristian Celtic and even pre-Celtic period, considered as the main manifestations of the divine, identified with the energy of the "Mother" (Jones, 1990, 6).

Generally speaking, all the currents and movements that have been presented in the previous paragraphs insist on a pantheistic and immanent conception of the divine as "physically present" in nature - a conception that, as it has already been said, is likely to have an impact also on the gender attribution. In fact, the "alternativeness" of these spiritual movements is also largely based on this gender aspect. This belief to the "Mother Gaia" (the life-creating energy and the earth) constitutes the point of demarcation from (mainly Roman Catholic) Christianity, which rather conveys a patriarchal conception of God (Jones, 2007, 48). In other words, the countercultural and New Age currents of the last two centuries were not only "alternative" because they opposed the modern life conditions, but also because they detached themselves from the mainstream religion. As it has already been mentioned, their "alternativeness" with this regard insists on a non-Father-based and non-transcendent conception of the divine itself, supporting a "God" that is incarnated in nature and in the own "self". What's more, this immanent element of spirituality has brought to the second "alternativeness", or rather detachment from the authority of the holy texts propagated by the Church (Heelas, 2008, 55). First, this rebellion affected the sacrament 
of marriage. For instance, Ida Hofmann and Henri Oedenkoven shocked the town villagers and their own families with their public disdain of marriage in its religious value and as a legal institution. Hofmann $(1906,18)$ claimed that love, as a manifestation of the original source of life, should be let enfold itself "in nature", without any constrictions. As it is wellknown, the Hippie movement of the 60s that gathered amongst others in Glastonbury supported the same "free love" approach, mainly with regard to sexuality (Aubrey and Shearlaw, 2005, 37). In the same way, the New Pagans refuse the ritual of the Christian marriage and they celebrate their own "alternative" wedding ceremonies during the seasonal festivals as a confirmation of a personal contract (Hunt, 2003, 152).

In conclusion, it is necessary to highlight the influence of the feminist movement of the "Jahrhundertwende" on these "Mother Gaia" discourses. For the women of Monte Verità, first of all for Ida Hofmann, the freedom from the Victorian ideal of the "angel of the home" as well as from any other form of inequality between the sexes (in politics, at school, at work and in the family) explicitly constituted one of the main goal of the "new" way of life (Landmann, 2000, 138 ff.). Similarly, the Goddess Movement founder Kathy Jones insists on the importance of providing women with institutional powers in the spiritual and religious realm, as it used to be for the Celtic Priestess (Jones, 2007, 66).

\section{Syncretism and Holism: The "New Age" Approach to Religion.}

As a consequence of the refusal to conform to the spiritual conceptions and to the religious practices of traditional Christianity, the "alternative" spiritualities of the last two centuries have turned their attention to other spiritual and religious traditions "other than" Christianity. These points of reference are either taken from earlier European religions (as for the New Pagans) or from other cultures, mostly from India and China (Prince \& Riches, 2000, p. 96). However, especially in the case of the more recent New Age, there is the tendency to intermingle all of them, the old European with the Eastern imports. This process mostly results in a syncretic system of eclectic beliefs which are meant to open "alternative" spiritual horizons. In the context of the more recent "alternative" spiritualities (with particular reference to the case of Glastonbury) Prince and Riches use the term "syncretism" rather than eclecticism (Prince and Riches, 2000, 33). Indeed, while "eclecticism" is a philosophical term referring to the plurality of the sources (L'universale. La Grande Enciclopedia Tematica, Vol. 1, 2003, 294), "syncretism" has been rather used within the religious field to point to the integration (or at least to the effort) of different traditions in a "new" one (L'universale. La Grande Enciclopedia Tematica, Vol. 2, 2003, 1059).

Again, Glastonbury is an exemplar case for this innovative and multicultural plurality of expression, from the healing movements to the Shekinashram, the non-dogmatic community for "Krishna Consciousness" (Garrard, 2014, 347). As it has already been mentioned in the previous chapter, yoga constituted one of the main practices on Monte Verità in combination with the cult of nature; in the same way, Gusto Gräser shaped his 
"Holy Mother" conception out of Taoism and Jesus' myth as apostle of poor/pureness. At this point, some personalities of Monte Verità are slightly different from most of the "alternatives" of Glastonbury in their relationship to Christianity. Indeed, in the first decades of the $20^{\text {th }}$ century Monte Verità used to be visited by so called "inflation saints" (mainly Gusto Gräser and Gustaf Nagel): wandering prophets whose appearance strongly reminded of Jesus, denouncing the decline of the contemporary society to materialism and alienation from God (Linse, 1983, 28, 47). In contrast to it, the Glastonbury "alternatives" have been more radically opposing the Christian religion in all its principles and forms being perhaps challenged by the still imposing authority of the Catholic Abbey, something that does not exist in the Monte Verità area. For instance, the Goddess Movement has often underlined how Christianity has overtaken the symbolism of the ancient Western civilization at the time of its conquest in order to reshape it according to its conceptions, as for the Glastonbury Tor, the symbol of the fish and the Holy Grail (Jones, 2007, 66, 72, 76).

Actually, there is more than one reason that explains this syncretic tendency of the "alternatives". From the historical point of view, the interest and the assimilation of other spiritual traditions can be traced back to the 20th-century theosophical attitude to find "the One in the Many", even among different religions (Kugler, 1995, $47 \mathrm{ff}$.). At the same time, this creative "mix-ing" can be regarded as the result of the great technologic and medial development of the last decades that has literally multiplied the possibility to access several "worlds" at once. Furthermore, Heelas (1996, 26 ff.) suggests that such Eastern imports like yoga as well as the natural religions perfectly apply to the needs of the Western (post)modern believer. First, these disciplines are highly individualized and individualizing: they can be practiced in private, everywhere, without any other constriction than the concentration on "one-self"; at the same time, they are open enough not to contrast with other spiritual and/or religious practices (one can practice yoga and take part to the rituals of the Catholic Church). Finally, Prince and Riches $(2000,33)$ claim that the enthusiastic embracement of non-Western and non-mainstream traditions (including magic and esoteric) among the New Agers is a way to distinguish themselves from the "orthodox scientific mainstream". As it has been mentioned at the beginning of the chapter, once the mainstream traditions are refused, it is necessary to find other alternatives to be proposed to the collectivity.

Nevertheless, one of the main reasons for the New Romantic spiritual and religious syncretism of pre-Christian and non-Western traditions lies also in the characteristics of these "others". In fact, both Eastern and tribal traditions (commonly known as "natural religions") share an approach to the world that matches the holistic view. Again, holism is a further key feature of the $20^{\text {th }}$-century and of the contemporary "alternatives". From a philosophical point of view, semantic holism designates the necessity to analyze an element in the wider context of its system in order to fully understand its meaning (L'universale. La Grande Enciclopedia Tematica, Vol. 2, 2003, 808). Similarly, the holistic 
outlook of the recent spiritual alternatives aims to endorse life as the manifestation of a complex system consisting of several levels and dimensions. As a result, both the environment and the human being are conceived as multi-dimensional and substantially interconnected. For this reason, each change or vibration taking place at one level and/or in one of both "systems" has an impact on the "whole" rest (Heelas, 1996, 33). The same conception lies at the basis of the "alternative" medicine practices promoted both on Monte Verità and Glastonbury: therapies and methods working on body, mind and spirit at the same time in the fight against illness (Garrard, 2014, 234). In this context, good health ("well-being") is conceived as an expression of balance, both within the human microcosm in itself (e.g. body and mind) and with the macrocosmic "world", whereas bad health ("IIIness") suggests a rupture or rather a distortion of this harmony. To summarize, the New Romantic naturist and holistic healing approach considers healing as fundamentally related to the spiritual; being "Mother Gaia" the first manifestation of the spirit of life, nature is the first source to come "back" to this balance, through its energy and its products. For this reason, so called "nature-based" methods (homeopathy, acupuncture, crystal and mineral healing) play a central role within "alternative" medicine as they are mostly put in opposition to the analytical and chemical methods of Western medicine (Heelas, 2008, 34).

Again, this belief in the healing powers of nature due to its "being" filled with spirit and substantially interconnected with the whole of the microcosmic human, matches with a pantheistic and immanent conception of the divine rather than with the transcendent Christian "Father in Heaven". For this reason, the contemporary "alternatives" rather turn to those "archaic civilizations" conceiving nature as a space for the sacred (Eliade, 1984, $16 \mathrm{ff}$.). Consequently, it is not surprising that the life-reformer of Monte Verità as well as the New Pagan of Glastonbury are keen on the same "Mother Earth" cults of the primitive nomadic hunters as well as of the settled tillers. However, it is necessary to remind that the relationship between nature and human being has dramatically changed from the prehistoric era to the $21^{\text {st }}$ century - and, consequently, even the goal of such earthbounded cults. Eliade $(1984,19)$ reminds that the primitive civilizations were radically dependent on the fertility of nature for their survival; this kind of relationship largely justifies its priority within the spiritual realm and the religious practices of the community. Whereas the human being the $20^{\text {th }}$ and $21^{\text {st }}$ century, thanks to the means provided by the industrial and technologic improvement, has a certain degree of autonomy in the production "for" his/her own life. Consequently, one could say that the main goal of the "new" "earthbounded cults consists in the revolution against the present social order, rather than in the mystic adoration of those super-human forces his/her life depends on. In other words, the new spiritualities and cries for "Mother Gaia" are focused on the relocation and redefinition of that link to nature that has lost its intensity as a consequence of the modern human autonomy/automatization. 


\section{Conclusion}

Summing up, Monte Verità and Glastonbury constitute two significant places to start the analysis of the "alternative" culture of the last two centuries as it has been developing in politics and in religion. For this reason, the first part of the paper (chapters 1 and 2) has described the historical development of these movements in both places. On the basis of this more or less empirical data, the second part of the paper (chapters 3, 4 and 5) has been dedicated to the reflection on the metaphysical discourses shared by all these movements, with a strong focus on the "spiritual".

The analysis has brought to the description of the $20^{\text {th }}$-century counterculture and of the contemporary New Age as "New Romantic Spiritualities and Cries for Mother Gaia". In fact, Heelas $(1996,42)$ agrees that the sacralization of nature and of the "self", which is central for the new alternatives, has to be traced back to the repertoire of the $19^{\text {th }}$-century Romantic movement. What's more, in the case of the New Romantic "alternatives" of the last two centuries, the sacralization of nature is expressed through what has been referred to as a naturist approach in the broad sense of the word: the attempt to come "back to Nature" first, by moving out of the polluted cities; second, by respecting those life-regulating rules provided by nature itself (e.g. cultivating seasonal products); third, by immerging one's own "self" into its "spirit" in order to (re)discover the meaning of life.

Actually, according to this naturist New Romantic approach "life" enfolds itself within the harmonic collaboration between human and nature/"cosmos"/environment. Indeed, both of them are considered to be lively entities that, being structurally multi-dimensional and interconnected, can have a great impact on each other. This conception lies at the basis of the various forms of "alternativeness" that have been presented so far: from the natural healing practices of so called "alternative" medicine (first of all homeopathy and diet cultures such as vegetarianism), to the New Pagan rituals to celebrate and get the energy from seasonal changes, to the political Green fight to save the planet. Again, the main goal of these "cries for Gaia" (whether spiritually-based or not) is an awakening of consciousness within the modern Western society - that the world shaped by the human being and the "other" one of nature need to support each other, rather than co-existing in the "winner takes it all-mode". In a Western society which is nowadays confronted with such dramatic question like nuclear power, the "alternatives" underline the necessity to "relocate" the way of life of the human being to a sustainable "win-to-win situation" both for the macro- and for the microcosm.

At the same time, this "alternative" approach should not only be contextualized as a reaction against the modern rationalization of the "cosmos". In fact, a further goal shared by the New Romantic "alternatives" is the detachment from the official Christian church, mainly identified with Roman Catholicism. In this case, the "alternatives" bring two main points of criticism: as regards content, the transcendent and patriarchal conception of God; as regards form, the great power given to the Church authority in spiritual matters, which 
are strictly categorized and regulated by its law. For the New Romantics, both are obstacles on the way "back to Nature - back to Life", basically because no freedom for "feeling" and "discovering" the own "truth" is left. From this point of view, the pantheistic pantheon/s of the natural pre-Christian religions and the strong holistic focus of the Eastern imports, together with the accentuation of the life-creating aspect of the divine through the "Mother", are more likely to fit into the "new romanticizing" way of being in the world.

To conclude, one could say that the "alternative" discourses of the $20^{\text {th }}$ and of the $21^{\text {st }}$ centuries such as those gathering around Monte Verità and Glastonbury are to be considered as signals of a socio-cultural turn. In fact, despite their radicalness which is first meant to be destructive, their "mission" implies the beginning of a transformation, which has been mostly put into practice within small circles or larger communities. Furthermore, the increasing popularity of these ways of living/thinking within Western society - just go to a supermarket and have a look at how the vegan products offer has changed in the last decades; or go to a fitness centre and look at the number of participants to yoga or tai-chi courses - should be interpreted as a symptomatic response to the "alternative" provocation. Confronted with the negative impacts of industrial and capitalist economy and stimulated by radical protest movements, the (post)modern West is entering a step in which the human-nature relationship must be relocated. Thus, this relocation affects also the spiritual and the religious aspects, since the relation to the "cosmos" implies the relation to the "other-than-human" which is located in and outside nature. For this reason, the "alternatives" have been strongly focusing on those "new" forms of spirituality that are thought to be more suitable for the "New Age" West: naturist, holistic and syncretic forms of religion. 


\section{References}

AUBREY, C. and SHEARLAW, J. (2005). Glastonbury. An Oral History of the Music, Mud \& Magic. London: Ebury Press.

BENHAM, P. (1993). The Avalonians. Glastonbury: Gothic Image Publications.

BERHORST, R. and BERG J. (2014) Karl Marx, 1867. System der Ausbeutung in GEO Epoche. 2014, Vol. 69, October, s. 56-73.

BERNARDINI, R. (2011). Jung a Eranos. Il progetto della psicologia complessa. Franco Angeli s.r.l.: Milano.

BREMER, T. S. (2004) The Genius loci ignotus of Eranos and the Making of Sacred Place in BARONE E.; RIEDL M. and TISCHEL A. (ed.) Pioniere, Poeten, Professoren. Eranos und der Monte Verità in der Zivilisationsgeschichte des 20. Jahrhunderts. 2004, Vol. 11, s. 79-82. Würzburg: Königshausen \& Neumann.

CAPT, R. E. (2008). The Traditions of Glastonbury. Muskogee: Artisan Publishers.

CHALICE WELL TRUST (2016). Chalice Well Healing Weekend [Online], Available http://www.chalicewell.org.uk/index.cfm/glastonbury/Events.Details/event_id/159 [6 April 2016].

DEDOLA, R. (2011) La verità sul monte e in riva al lago in SCATEGNI W. (ed.) and LIVORSI F. (ed.). II mistero di Eranos tra passato e presente. Civiltà e spiritualità tra Oriente e Occidente dal punto di vista della Psicologia Analitica (e dintorni). 2011, s. 42-58. Alessandria: Edizioni Falsopiano.

ELIADE, M. (1984). Das Heilige und das Profane. Frankfurt am Main and Leipzig: Insel Taschenbuch 2242, 1998. Reprint 1984.

FOLINI, M. (2000). Monte Verità: Ascona's Mountain of Truth. Berne: Society for the History of Swiss Art (SHSA).

GARRARD, B. (2014). Free State. Glastonbury's alternative community 1970 to 2000 and beyond. Glastonbury: Unique Publications.

HAMMER, A. (2013) Religion und Literatur in NÜNNING, A. (ed.) Metzler Lexikon. Literatur- und Kulturtheorie. Ansätze - Personen - Grundbegriffe, 5th Edition. 2013, s. 644-646. Stuttgart and Weimar: Verlag J.B. Metzler.

HEELAS, P. (1996). The New Age Movement. The Celebration of the Self and the Sacralization of Modernity. Oxford: Blackwell Publishers Ltd.

HEELAS, P. (2008). Spiritualities of Life. New Age Romanticism and Consumptive Capitalism. Oxford: Blackwell Publishing Ltd. http://dx.doi.org/10.1002/9781444301106

HOPKINSON-BALL, T. (2007). The Rediscovery of Glastonbury. Frederick Bligh Bond. Architect of the New Age. Stroud: Sutton Publishing.

KOZLJANIČ, R. J. (2004). Der Geist eines Ortes. Kulturgeschichte und Phänomenologie des Genius Loci, Antike-Mittelalter, Vol. 1. München: Albunea Verlag.

KOZLJANIČ, R. J. (2004). Der Geist eines Ortes. Kulturgeschichte und Phänomenologie des Genius Loci. Neuzeit - Gegenwart, Vol. 2. München: Albunea Verlag.

HOFMANN, I. (1906). Monte Verità. Wahrheit ohne Dichtung. Aus dem Leben erzählt von Ida HofmannOedenkoven. Lorch: Karl Rohm Verlag.

HUNT, S. J. (2003). Alternative Religions. A Sociological Introduction. Farnham: Ashgate Publishing. 
JONES, K. (2007). In the Nature of Avalon. Goddess Pilgrimages in Glastonbury's Sacred Landscape. Glastonbury: Ariadne Publications.

JONES, K. (1990). The Goddess in Glastonbury. Glastonbury: Ariadne Publications.

L'universale. La Grande Enciclopedia Tematica. Filosofia A - Lib, Vol. 1 (2003). Milano: Garzanti Libri.

L'universale. La Grande Enciclopedia Tematica. Filosofia Lib - Z, Vol. 2 (2003). Milano: Garzanti Libri.

LANDMANN, R. (2000). Ascona - Monte Verità. Auf der Suche nach dem Paradies. Frauenfeld: Verlag Huber, 2009. Reprint 2000.

LINSE, U. (1983). Barfüßige Propheten. Erlöser der zwanziger Jahre. Berlin: Siedler.

MARTINONI, M. (1995) Monte Verità uno strumento culturale in Box 61, Folder 1.2.5, Fondo Harald Szeemann dell'Archivio Fondazione Monte Verità. Bellinzona.

MCKAY, G. (2000). Glastonbury. A very English Fair. London: Victor Gollancz.

MERLEAU-PONTY, M. (1966). Phänomenologie der Wahrnehmung. Berlin: Walter de Gruyter \& Co. http://dx.doi.org/10.1515/9783110871470

MONTE VERITÀ (2016). Guided Tours [Online], Available http://www.monteverita.org/en/39/default.aspx [6 April 2016].

MICHELL, J. (1983). The New View Over Atlantis. London: Thames and Hudson.

MÜLLER, H. (2016). Gusto Gräser. TAO. Das heilende Geheimnis, $3^{\text {rd }}$ Edition. Recklingshausen: Umbruch Verlag.

NOSCHIS, K. (2011). Monte Verità. Ascona et le génie du lieu, Vol. 73. Lausanne: Presses polytechniques et universitaires romandes.

PRINCE, R. and RICHES, D (2000). The New Age in Glastonbury. The Construction of Religious Movements. Oxford and New York: Berghahn Books.

PYTLIK, P. (2005). Okkultismus und Moderne: ein kulturhistorisches Phänomen und seine Bedeutung für die Literatur um 1900. Paderborn: Schöningh.

SCHÖNENBERGER, W. (1978) Monte Verità und die theosophischen Ideen in SZEEMANN, H. (ed.) Monte Verità Ascona. Die Brüste der Wahrheit. 1978, s. 65-79. Milano: Electa.

SIMEK, R. (2012). Artus-Lexikon: Mythos und Geschichte, Werke und Personen der europäischen Artusdichtung. Stuttgart: Reclam.

VOSWINCKEL, U. (2009). Freie Liebe und Anarchie. Schwabing - Monte Verità. Entwürfe gegen das etablierte Leben. München: Allitera Verlag.

WEDEMEYER, B. (2001) Culto del corpo e attività sportiva. Un centro di cultura fisica all'avanguardia al Monte Verità in SCHWAB A. (ed.) and Lanfranchi, C. (ed.) Senso della vita e bagni di sole. Esperimenti di vita e arte al Monte Verità. 2001, s. 90-104. Ascona: Fondazione Monte Verità.

WESTWOOD J. and SIMPSON, J. (2005). The Lore of the Land. A Guide to England's Legends, from SpringHeeled Jack to the Witches of Warboys. London: Penguin Books. 